УДК 631.95:633.11

DOI https://doi.org/10.32848/agrar.innov.2021.5.2

\title{
ЗАСТОСУВАННЯ МІКРОБНИХ ПРЕПАРАТІВ І РЕГУЛЯТОРІВ РОСТУ РОСЛИН ДЛЯ ЗНИЖЕННЯ НАКОПИЧЕННЯ ВАЖКИХ МЕТАЛІВ У ЗЕРНІ ПШЕНИЦІ ОЗИМОЇ
}

\author{
БОНДАРЕВА О.Б. - кандидат технічних наук, старший науковий співробітник \\ http://orcid.org/0000-0002-8128-8485 \\ Донецька державна сільськогосподарська дослідна станція \\ Національної академії аграрних наук України \\ ВІнЮкОВ О.О. - доктор сільськогосподарських наук, старший дослідник \\ http://orcid.org/0000-0002-2957-5487 \\ Донецька державна сільськогосподарська дослідна станція \\ Національної академії аграрних наук України \\ КОНОВАЛЕНКО Л.І. - кандидат хімічних наук \\ http://orcid.org/0000-0003-0387-4603 \\ Донецька державна сільськогосподарська дослідна станція \\ Національної академії аграрних наук України
}

\begin{abstract}
Постановка проблеми. Одним зі стратегічних напрямів розвитку сучасного аграрного виробництва $€$ забезпечення населення екологічно безпечними, високоякісними продуктами харчування, оскільки це визначає якість життя людини. Екологічну небезпеку рослинної продукції пов'язують із умістом надлишкових концентрацій хімічних токсикантів, серед яких пріоритетними є важкі метали (BM): цинк (Zn), мідь (Cu), свинець $(\mathrm{Pb})$, кадмій (Cd) [1].

В останні десятиріччя в регіонах із розвинутою промисловістю спостерігається локальне нагромадження рухомих форм важких металів у ґрунті, доступних до накопичення в рослинах. Основна небезпека важких металів полягає у здатності біоконцетруватися та викликати канцерогенні, мутагенні та тератогенні ефекти. Вони можуть забруднювати ґрунти, змінювати його агрохімічні, мікробіологічні, екологічні властивості, мігрувати і забруднювати поверхневі та ґрунтові води [2].

Збільшення вмісту ВМ у навколишньому середовищі і накопичення їх у ґрунті завдають негативного впливу на біоту в цілому, включаючи рослини, які $є$ одним із найбільш чутливих її компонентів. Отже, виникає необхідність пошуку агрозаходів, які забезпечують зменшення поглинання важких металів рослинами.
\end{abstract}

Аналіз останніх досліджень і публікацій. Актуальність вивчення процесів переходу ВМ із ґрунту в рослини полягає у тому, що рослинність виступає проміжною ланкою міграції ВМ між ґрунтом і організмом людини. Особливості поглинання важких металів із ґрунту рослинністю вивчали В.В. Ковальський, А. КабатаПендіас, А.І. Фатєєв, С.А. Балюк, М.М. Мірошниченко, Н.А. Макаренко, М.А. Глазовська, В.Б. Ільїн та ін. [2-7]. Однак це питання залишається недостатньо вивченим, зокрема в аспекті безпечності зерна, яке вирощуються в зоні впливу високого техногенного навантаження.

На сучасному етапі розвитку сільськогосподарського виробництва великого значення набуває широке використання агентів біологічного впливу, що передбачає застосування нових ефективних та екологічно безпечних стимуляторів росту, мікродобрив та мікробіологічних препаратів, які здатні регулювати процеси життєдіяльності рослин та ґрунтової мікрофлори [8-13]. Безліч регуляторів росту рослин і біопрепаратів, створених на основі живих мікроорганізмів, володіють ріст-стимулюючими властивостями, мають антистресову й імуностимулюючу активність. Разом із цим застосування препаратів із ріст-активуючою функцією на забруднених ґрунтах може призвести до змін у накопиченні рослинами хімічних токсикантів [12]. Однак застосування регуляторів росту як інструменту захисту і зниження токсичної дії важких металів на рослини мало вивчено і потребує досліджень з урахуванням регіональних особливостей. Для регіонів із високим рівнем техногенного навантаження на агроценози проблема відповідності сільгосппродукції сучасним стандартам якості залишається надзвичайно актуальною.

Мета статті. Мета статті - проаналізувати вплив комплексного застосування інокуляції насіння пшениці озимої біопрепаратами з обробкою рослин стимуляторами на накопичення важких металів у зерні в умовах техногенного навантаження.

Матеріали і методика досліджень. Досліди проводилися у сівозміні ДП «ДГ «Забойщик» ДДСДС НААН» Великоновоселківського району Донецької області. Схема досліду передбачала передпосівну обробку насіння діазофітом, поліміксобактерином 100 мл на 1 гектарну норму насіння 3 подальшим обприскуванням вегетуючих рослин розчином рідкої гумінової суміші айдар і вермістім дозою 8 л/га. Обробіток ґрунту звичайний, загальноприйнятий у господарствах області. Технологія вирощування пшениці озимої загальноприйнята в господарствах області. Посівна площа ділянки - 88,2 м², облікова - 62,7 м², повторність - триразова, розміщення ділянок систематичне.

Методи дослідження: загальнонаукові - аналіз і узагальнення наукових положень, польовий, лабораторний, статистичні.

У зерні пшениці озимої і ґрунті досліджували вміст міді, цинку, свинцю і кадмію, які $€$ пріоритетними забруднювачами агроландшафтів Донецької області. Зразки ґрунту відбирали в шарі 0-20 см згідно з дСТУ ISO 10381-1:2004, ДСТУ ISO 10381-2:2004 «Якість ґрунту. Відбирання проб». Підготовку ґрунту для аналізу проводили за стандартними методиками. Екстракцію 
потенційно рухомих форм важких металів із ґрунту проводили згідно з чинними методиками $1 \mathrm{M} \mathrm{HNO}$. Відбір рослинних зразків для проведення агрохімічних досліджень проводили відповідно до «Методичних указівок із проведення досліджень у довготривалих дослідах із добривами», ч. 1, 2., М., 1980. Важкі метали в рослинних зразках визначали в їх зольних розчинах після спалювання методом сухої мінералізації.

Уміст важких металів у зразках, що досліджуються, визначили атомно-абсорбційним методом на КАС-120.1 у режимі електротермічної атомізації відповідно до «Методических указаний по определению тяжелых металлов в почвах сельхозугодий и продукции растениеводства» (Москва : ЦИНАО, 1992 ; Методи аналізів ґрунтів і рослин : методичний посібник. Кн. 1 / за ред. С.Ю. Булигіна та ін. Харків, 1999. 157 с.). Статистичну обробку результатів проводили згідно з Б.О. Доспєховим [14].

Результати досліджень. Забруднення природного середовища важкими металами, зумовлене техногенними викидами промислових комплексів, $€$ реальною загрозою отриманню екологічно безпечної продукції, тому завдання зменшення накопичення важких металів у врожаї сільськогосподарських культур залишається актуальним, особливо для індустріальних регіонів.

Для підвищення адаптаційних властивостей рослин до екологічних стресорів, а також надійності отримання якісного й екологічно безпечного зерна в зонах високого техногенного навантаження на агроландшафти уявляється доцільним вивчення комплексної дії біостимуляторів і мікробних препаратів на рослини в умовах техногенезу.

Для вирішення цього завдання було досліджено вплив інокуляції насіння пшениці озимої мікробними препаратами діазофріт і поліміксобактерин у комплексі з позакореневою обробкою посівів регуляторами росту рослин рідкою гуміновою сумішшю айдар і вермістім на показники відповідності зерна санітарно-гігієнічним нормам, які визначаються, зокрема, вмістом важких металів [15].

Застосування мікробних препаратів для передпосівної обробки насіння озимої пшениці й обприскування посівів регуляторами росту рослин забезпечило підвищення польової схожості, поліпшення перезимівлі i, як результат, підвищення продуктивності культури (табл. 1).

Максимальний урожай у досліді отримано за комплексного застосування інокуляції посівного матеріалу мікробними препаратами з позакореневою обробкою посівів стимуляторами росту рослин.
Таблиця 1 - Урожайність пшениці озимої сорту Богиня (2019-2020 рр.)

\begin{tabular}{|l|c|c|c|}
\hline \multirow{2}{*}{ Варіант досліду } & Урожайність, & \multicolumn{2}{|c|}{ Прибавка, } \\
\cline { 3 - 4 } & т/га & т/га & $\%$ \\
\hline $\begin{array}{l}\text { Контроль } \\
\text { (вода, без препаратів) }\end{array}$ & 7,10 & - & - \\
\hline Діазофріт & 7,70 & 0,60 & 8,5 \\
\hline Поліміксобактерин & 7,89 & 0,79 & 11,1 \\
\hline Діазофіт +айдар & 7,97 & 0,87 & 12,3 \\
\hline Діазофіт +верместім & 7,83 & 0,73 & 10,3 \\
\hline Поліміксобактерин+айдар & 8,08 & 0,98 & 13,8 \\
\hline Поліміксобактерин+верместім & 8,01 & 0,91 & 12,8 \\
\hline HІР $_{\text {0,5,тга }}$ & 0,19 & & \\
\hline
\end{tabular}

Додатковий урожай відносно контролю над застосуванням мікробних препаратів становив для діазофіту 0,60 т/га (8,5\%), поліміксобактерину - 0,79 т/га $(11,1 \%)$. За комплексного застосування мікробних препаратів разом зі стимуляторами росту рослин прибавка врожаю збільшилася і становила 0,87-0,98 т/га, або 12,3-13,8\%. Найбільш ефективним було поєднання інокуляції насіння поліміксобактерином з обробкою вегетуючих рослин гуміновою сумішшю айдар. Урожайність у цьому варіанті становила 8,08 т/га, що достовірно перевищило контроль на 0,98 т/га (13,8\%).

Для оцінки якості продукції було проведене аналітичне визначення вмісту важких металів у зерні (табл. 2).

Експериментально встановлено, що в усіх варіантах досліду вміст найбільш поширених важких металів (міді, цинку, кадмію, свинцю) не перевищував гранично допустимі концентрації. Отримані результати свідчать, що комплексне застосування мікробних препаратів і позакореневої обробки посівів розчином біостимуляторів рослин айдар і вермістім сприяє зменшенню поглинання найбільш небезпечних елементів свинцю і кадмію в зерні пшениці озимої. Так, уміст свинцю зменшився проти контрольного варіанту на 31-43\%, кадмію - на 29-35\%. Це робить такий агрозахід доцільним під час вирощування зерна з показниками якості відповідно до санітарно-гігієнічних вимог у зонах високого техногенного навантаження.

Для визначення кількісних параметрів міграції ВМ із ґрунту в рослини пшениці озимої розраховували коефіцієнти біологічного поглинання (Кб.п), які дають можливість оцінити вплив технології на процеси накопичення важких

Таблиця 2 - Вплив мікробних препаратів і стимуляторів росту рослин на вміст важких металів у зерні пшениці озимої сорту Богиня

\begin{tabular}{|c|c|c|c|c|c|c|c|c|c|c|c|c|}
\hline \multirow[t]{3}{*}{ Варіант досліду } & \multicolumn{12}{|c|}{ Вміст важких металів, мг/кг } \\
\hline & \multicolumn{3}{|l|}{$\mathrm{Cu}$} & \multicolumn{3}{|l|}{$\mathrm{Zn}$} & \multicolumn{3}{|l|}{$\mathrm{Pb}$} & \multicolumn{3}{|l|}{$\mathrm{Cd}$} \\
\hline & 1 & 2 & 3 & 1 & 2 & 3 & 1 & 2 & 3 & 1 & 2 & 3 \\
\hline Контроль (вода) & 6,2 & 5,9 & 5,0 & 27,4 & 25,1 & 25,5 & 0,36 & 0,26 & 0,29 & 0,082 & 0,071 & 0,072 \\
\hline Діазофріт & 5,5 & 4,5 & 4,5 & 25,8 & 24,3 & 24,4 & 0,28 & 0,22 & 0,25 & 0,067 & 0,058 & 0,064 \\
\hline Поліміксобак-терин & 5,0 & 4,7 & 4,9 & 25,1 & 23,6 & 24,0 & 0,21 & 0,15 & 0,20 & 0,056 & 0,046 & 0,051 \\
\hline $\mathrm{HIP}_{0,5}$ & \multicolumn{3}{|l|}{0,63} & \multicolumn{3}{|l|}{1,0} & \multicolumn{3}{|l|}{0,05} & \multicolumn{3}{|l|}{0,008} \\
\hline
\end{tabular}

Примітки: 1, 2, 3 - варіанти обприскування посівів на тлі передпосівної обробки насіння: 1 - контроль (вода), 2 - айдар, 3 - вермістім 
Таблиця 3 - Вплив мікробних препаратів і біостимуляторів рослин на інтенсивність біоакумуляції свинцю і кадмію в зерні пшениці озимої

\begin{tabular}{|c|c|c|c|c|c|c|}
\hline \multirow{3}{*}{ Варіант досліду } & \multicolumn{6}{|c|}{ Коефіцієнт біологичного поглинання } \\
\hline & \multicolumn{3}{|c|}{$\mathbf{P b}$} & \multicolumn{3}{|c|}{ Cd } \\
\hline & 1 & 2 & 3 & 1 & 2 & 3 \\
\hline Контроль (вода) & 0,18 & 0,13 & 0,15 & 0,19 & 0,17 & 0,17 \\
\hline Діазофіт & 0,14 & 0,11 & 0,13 & 0,16 & 0,13 & 0,15 \\
\hline Поліміксобактерин & 0,11 & 0,08 & 0,10 & 0,13 & 0,11 & 0,12 \\
\hline
\end{tabular}

Примітки: 1, 2, 3 - варіанти обприскування посівів на тлі передпосівної обробки насіння: 1 - контроль (вода), 2 - айдар, 3 - вермістім

металів рослинами. Кбп визначали за співвідношенням умісту металу в рослині до його вмісту в ґрунті (табл. 3). Попередньо аналітично встановлено вміст потенційно рухомих фрорм свинцю і кадмію в ґрунті дослідного поля, яке розташоване в зоні впливу Кураховської ТЕС. Експериментально визначена концентрація потенційно рухомого свинцю в ґрунті $(2,0 \pm 0,16$ мг/кг) та потенційно рухомого кадмію $(0,43 \pm 0,09$ мг/кг).

Максимальний позитивний ефект дало комплексне застосування поліміксобактерину і біостимулятору айдар. У цьому варіанті накопичення свинцю в зерні пшениці озимої знизилося в 2,3 рази, кадмію - в 1,8 рази. Кбп на контролі становив для $\mathrm{Pb}-0,18$, з обробкою $-0,08$, для $\mathrm{Cd}-0,19$ і 0,11 відповідно. Використання вермістіму забезпечило практично такий самий ефект. 3 обробкою вермістімом Кбп для свинцю був 0,10, для кадмію - 0,12, уміст свинцю знизився в 1,8 рази, кадмію - в 1,6 рази. Це пов'язано з утворенням малорухомих сполук із фосфатами і підвищенням стійкості рослин до транслокації важких металів.

Висновки. Бактеризація насіння пшениці озимої й обприскування посівів регуляторами росту рослин забезпечило підвищення продуктивності культури. Додатковий урожай відносно контролю з бактеризацією насіння становив для діазофріту 0,60 т/га (8,5\%), поліміксобактерину - 0,79 т/га (11,1\%). Найбільший додатковий урожай дало поєднання інокуляції насіння поліміксобактерином з обробкою вегетуючих рослин гуміновою сумішшю айдар. Урожайність у цьому варіанті становила 8,08 т/га, що достовірно перевищило контроль на 0,98 т/га (13,8\%).

Комплексне застосування мікробних препаратів і позакореневої обробки посівів розчином біостимуляторів рослин айдар і вермістім сприяє зменшенню поглинання найбільш небезпечних елементів свинцю і кадмію в зерні пшениці озимої (на 31-43\% та на 29-35\% проти контрольного варіанту).

Виявлено протекторну дію поліміксобактерину в комплексі зі стимуляторами айдар і вермістім до найбільш небезпечних елементів свинцю і кадмію. Уміст $\mathrm{Pb}$ у зерні пшениці озимої знижується в 1,8-2 рази, Cd в 1,6-1,8 рази. Коефіцієнт біологічного поглинання на контролі становив для $\mathrm{Pb}-0,18$, з обробкою -0,08-0,10, для $\mathrm{Cd}-0,19$ і 0,11-0,12 відповідно. Застосування таких агрозаходів дає змогу зменшити ризик забруднення зернової продукції під час вирощування в умовах промислових регіонів із високим рівнем техногенного навантаження на агросферу.

\section{СПИСОК ВИКОРИСТАНОЇ ЛІТЕРАТУРИ:}

1. Некос А.Н. Акумулятивні властивості рослин як фрактор формування екологічної безпеки рослинної харчової продукції (на прикладі Харківського регіону). Людина та довкілля. Проблеми неоекології. 2012. № 1-2. C.100-107.

2. Екологічна ситуація в зоні впливу Зміївської ТЕС / за заг. ред. С.А. Балюк. Харків : Бровін О.В., 2019. 88 с.

3. Кабата-Пендиас А., Пендиас Х. Микроэлементы в почвах и растениях. Москва, 1989. 439 с.

4. Фатєєв Ф.І., Самохвалова В.Л. Концепція використання техногенно забруднених ґрунтів. Харків : Стильна типографія, 2018. 57 с.

5. Ильин В.Б. Тяжелые металлы в системе «почва растение». Новосибирск : Наука, 1991. 151 с.

6. Бондарь В.І., Макаренко Н.А. Вплив технологій вирощування пшениці озимої на процеси акумуляції і транслокації свинцю. Біоресурси і природокористування. 2019. T. 11. № 1-2. C. 41-50. URL: https://doi.org/10.31548/bio2019.01.005.

7. Фатєєв A.I. Вплив систем удобрення на рухомість кадмію в темно-сірому опідзоленому ґрунті Західного Лісостепу України. Агрохімія $і$ грунтознавство. 2015. Вип. 82. С. 33-36. URL: http://nbuv.gov.ua/ UJRN/agrohimigrn_2015_82_7.

8. Гаврилюк В.А., Дідковська Т.П. Ефективність використання нових видів мікробіологічних препаратів і стимуляторів росту. Вісник ХНАУ. Серія «Ґрунтознавство, агрохімія, землеробство, лісове господарство». 2008. № 4. С. 49-52.

9. Використання біопрепаратів - перспективний напрямок вдосконалення агротехнологій / М.О. Остапчук та ін. Сільське господарство та лісівництво. 2015. № 2. C. 5-17.

10. Найдьонова О.Є. Застосування гумінового препарату «Humin plus» в органічному землеробстві. Вісник ХНАУ. 2015. № 2. С. 39-50.

11. Урожайність і якість насіння сільськогосподарських культур за дії регуляторів росту рослин / М.Г. Василенко та ін. Агроекологічний журнал. 2018. № 1. С. 96-101.

12. Эффрективность предпосевной обработки семян яровой пшеницы микробиологическим препаратом бисолбисан в условиях загрязнения почвы кадмием / Л.Н. Ульяненко и др. Агрохимия. 2009. № 3. С. 76-83.

13. Транслокація важких металів у системі «ґрунт рослина» за вапнування та впливу біологічних препаратів / С.Г. Корсун та ін. Агроекологічний журнал. 2019. № 1. С. 29-35. DOI: https://doi.org/ 10.33730/2077-4893.1.2019.163245. 
14. Доспехов Б.А. Методика полевого опыта. Москва : Агропромиздат, 1985. $351 \mathrm{c.}$

15. ДСТУ 3768:2010. Пшениця. Технічні умови.

\section{REFERENCES}

1. Nekos, A.N. (2012). Akumulyatyvni vlastyvosti roslyn yak faktor formuvannya ekolohichnoyi bezpeky roslynnoyi kharchovoyi produktsiyi (na prykladi Kharkivskoho rehionu) [Accumulative properties of plants as a factor in the formation of environmental safety of plant foods (on the example of the Kharkiv region)]. Lyudyna ta dovkillya. Problemy neoekolohiyi - Man and the environment. Problems of neoecology, 1-2, 100-107 [in Ukrainian].

2. Balyuk, S.A. (Eds.). (2019). Ekolohichna sytuatsiya $v$ zoni vplyvu Zmiyivskoyi TES [Ecological situation in the zone of influence of Zmiiv TPP]. Kharkiv: Brovin O.V. [in Ukrainian].

3. Kabata-Pendias, A., \& Pendias, H. (1989). Mykroélementy $v$ pochvakh y rastenyyakh [Trace elements in soils and plants]. Moscow [in Russian].

4. Fateev, F.I., \& Samokhvalova, V.L. (2018). Kontseptsiya vykorystannya tekhnohenno zabrudnenykh hruntiv [The concept of using man-made contaminated soils]. Kharkiv : Stylna typohrafiya [in Ukrainian].

5. Ilyin, V.B. (1991). Tyazhelye metally $v$ systeme "pochva - rastenye» [Heavy metals in the soil-plant system]. Novosibirsk: Nauka [in Russian].

6. Bondar, V.I., \& Makarenko, N.A. (2019). Vplyv tekhnolohiy vyroshchuvannya pshenytsi ozymoyi na protsesy akumulyatsiyi i translokatsiyi svyntsyu. [Influence of winter wheat cultivation technologies on lead accumulation and translocation processes]. Bioresursy i pryrodokorystuvannya - Bioresources and nature management, 11, 1-2, 41-50. https://doi.org/10.31548/bio2019.01.005 [in Ukrainian].

7. Fateev, A.I. (2015). Vplyv system udobrennya na rukhomist kadmiyu $v$ temno-siromu opidzolenomu grunti Zakhidnoho Lisostepu Ukrayiny [Influence of fertilizer systems on cadmium mobility in dark gray podzolic soil of the Western Forest-Steppe of Ukraine]. Ahrokhimiya i gruntoznavstvo - Agrochemistry and soil science, 82, 33-36. http://nbuv.gov.ua/UJRN/ agrohimigrn 2015827 [in Ukrainian].

8. Gavrilyuk, V.A., \& Didkovskaya, T.P. (2008). Efektyvnist vykorystannya novykh vydiv mikrobiolohichnykh preparativ i stymulyatoriv rostu [The effectiveness of new types of microbiological drugs and growth stimulants]. Visnyk KHNAU (Ser. "Gruntoznavstvo, ahrokhimiya, zemlerobstvo, lisove hospodarstvo») Bulletin of KhNAU (Ser. "Soil Science, Agrochemistry, Agriculture, Forestry"), 4, 49-52 [in Ukrainian].

9. Ostapchuk, M.O., Polishchuk, I.S., Mazur O.V., \& Maksimov, A.M. (2015). Vykorystannya biopreparativ - perspektyvnyy napryamok vdoskonalennya ahrotekhnolohiy [The use of biological products is a promising area for improving agricultural technologies]. Silske hospodarstvo ta lisivnytstvo - Agriculture and forestry, 2, 5-17 [in Ukrainian].

10. Naidenova, O.E. (2015). Zastosuvannya huminovoho preparatu "Humin plus» v orhanichnomu zemlerobstvi [The use of humic drug "Humin plus" in organic farming]. Visnyk KHNAU - Bulletin of KhNAU, 2, 39-50 [in Ukrainian].
11. Vasilenko, M.G., Stadnik,A.P., Dushko, P.M., etal. (2018). Urozhaynist i yakist nasinnya silskohospodarskykh kultur za diyi rehulyatoriv rostu Roslyn [Yield and quality of seeds of agricultural crops under the action of plant growth regulators]. Ahroekolohichnyy zhurnal Agroecological journal, 1, 96-101 [in Ukrainian].

12. Ulyanenko, L.N., Filipas, A.S., Loy N.N., et al. (2009). Éffektyvnost predposevnoy obrabotky semyan yarovoy pshenytsy mykrobyolohycheskym preparatom bysolbysan $v$ uslovyyakh zahryaznenyya pochvy kadmyem [Efficiency of pre-sowing treatment of spring wheat seeds with the microbiological preparation bisolbisan in the conditions of soil contamination with cadmium] Ahrokhymyya -Agrochemistry, 3, 76-83 [in Russian

13. Korsun, S.G., Klimenko, I.I., Bolokhovskaya, V.A., \& Bolokhovsky, V.V. (2019). Translokatsiya vazhkykh metaliv u systemi "grunt - roslyna» za vapnuvannya ta vplyvu biolohichnykh preparativ [Translocation of heavy metals in the system "soil - plant" under liming and exposure to biological products]. Ahroekolohichnyy zhurnal Agroecological journal, 1, 29-35 https://doi.org/ 10.33730/2077-4893.1.2019.163245 [in Ukrainian].

14. Dospekhov, B.A. (1985). Metodyka polevoho opyta [Methods of field experience]. M. : Agropromizdat [in Russian].

15. Pshenytsya. Tekhnichni umovy [Wheat. Specifications]. (2010). DSTU 3768: 2010 [in Ukrainian].

Бондарева О.Б., Вінюков О.О., Коноваленко Л.І. Застосування мікробних препаратів і регуляторів росту рослин для зниження накопичення важких металів у зерні пшениці озимої

Мета. Провести аналіз впливу комплексного застосування інокуляції насіння пшениці озимої біопрепаратами з обробкою рослин стимуляторами на накопичення важких металів у зерні в умовах техногенного навантаження. Методи. Польовий, лабораторний, розрахунковий і статистичний, аналізу і синтезу.

Результати. Встановлено, що бактеризація насіння пшениці озимої й обприскування посівів регуляторами росту рослин забезпечили підвищення продуктивності пшениці озимої. Додатковий урожай відносно контролю з бактеризацією насіння становив для діазофріту 0,60 т/га (8,5\%), поліміксобактерину - 0,79 т/га (11,1\%). Найбільший додатковий урожай дало поєднання інокуляції насіння поліміксобактерином з обробкою вегетуючих рослин гуміновою сумішшю айдар. Урожайність у цьому варіанті становила 8,08 т/га, що достовірно перевищило контроль на 0,98 т/га (13,8\%). Для оцінки якості продукції було проведене аналітичне визначення вмісту важких металів у зерні. Комплексне застосування мікробних препаратів і позакореневої обробки посівів розчином біостимуляторів рослин айдар і вермістім сприяє зменшенню поглинання найбільш небезпечних елементів свинцю і кадмію в зерні пшениці озимої (на $31-43 \%$ та на 29-35\% проти контрольного варіанту), що дає змогу одержувати зерно з показниками якості відповідно до санітарно-гігієнічних вимог. Поліміксобактерин за комплексного застосування зі стимуляторами айдар і вермістім виявляє протекторну дію до свинцю і кадмію, оскільки знижує вміст надходження цих елементів у рослини пшениці озимої. Максимальний позитивний ефект дало комплексне застосування поліміксобактерину і біостимулятору айдар. У цьому варіанті накопичення 
свинцю в зерні пшениці озимої знизилося в 2,3 рази, кадмію - в 1,8 рази. Коефріцієнт біологічного поглинання на контролі становив для свинцю $-0,18$, з обробкою 0,08, для кадмію - 0,19 і 0,11 відповідно.

Висновки. Застосування таких агрозаходів дає змогу зменшити ризик забруднення зернової продукції під час вирощування пшениці озимої в умовах промислових регіонів із високим рівнем техногенного навантаження на агросферу.

Ключові слова: зерно, біопрепарати, інокуляції насіння, обприскування посівів, протекторна дія, коефіцієнт біологічного поглинання.

Bondareva O.B., Vinyukov O.O., Konovalenko L.I. The use of microbial preparations and plant growth regulators to reduce the accumulation of heavy metals in the grain of winter wheat

Purpose. To analyze the impact of integrated application of inoculation of winter wheat seeds with biopreparations with treatment of plants with stimulants on the accumulation of heavy metals in the grain under man-made load. Methods. Field, laboratory, computational and statistical, analysis and synthesis. Results. It was found that bacterization of winter wheat seeds and spraying of crops with plant growth regulators provided an increase in the productivity of winter wheat. The additional yield relative to control with seed bacterization was 0,60 t/ha for diazophyte $(8,5 \%)$ and $0,79 \mathrm{t} / \mathrm{ha}$ for polymyxobacterin $(11,1 \%)$. The greatest additional yield was given by the combination of inoculation of seeds with polymyxobacterin with treatment of vegetative plants with a humic mixture of aydar. The yield in this variant was $8,08 \mathrm{t} / \mathrm{ha}$, which significantly exceeded the control by 0,98 t/ha $(13,8 \%)$. To assess product quality, an analytical determination of the content of heavy metals in the grain was performed. The complex use of microbial preparations and foliar treatment of crops with a solution of biostimulants of plants aidar and vermistim reduces the absorption of the most dangerous elements of lead and cadmium in winter wheat grain (by $31-43 \%$ and $29-35 \%$ against the control option), which allows to obtain grain with quality indicators in accordance with sanitary and hygienic requirements. Polymyxobacterin for complex use with stimulants aydar and vermistim has a protective effect against lead and cadmium, as it reduces the content of these elements in the plants of winter wheat. The maximum positive effect was given by the complex use of polymyxobacterin and the biostimulator aydar. In this variant, the accumulation of lead in the grain of winter wheat decreased by 2,3 times, cadmium - by 1,8 times. The biological absorption coefficient on the control was 0,18 for lead, 0,08 with treatment, 0,19 and 0,11 for cadmium, respectively. Conclusions. The use of such agricultural measures makes it possible to reduce the risk of contamination of grain products in the cultivation of winter wheat in industrial regions with a high level of man-made load on the agrosphere.

Key words: grain, biopreparations, seed inoculation, crop spraying, protective effect, biological absorption coefficient. 